\title{
ON WEIGHTED EULER HARMONIC IDENTITIES WITH APPLICATIONS
}

\author{
A. Aglić Aljinović, Lu. Dedić, M. Matić And J. PeČArić
}

\begin{abstract}
A weighted Euler identities involving harmonic sequences of functions are established. Consequently various generalizations of Ostrowski inequality involving weighted integrals are obtained.
\end{abstract}

Mathematics subject classification (2000): 26D15, 26D20.

Key words and phrases: Euler identities, harmonic sequences of functions, Ostrowski inequality.

\section{REFERENCES}

[1] A. Aglić Aljinović, J. PeČARIĆ, The weighted Euler identity, Math. Inequal. Appl., 8, 2 (2005), 207-221.

[2] A. Aglić Aljinović, J. PeČARIĆ, A discrete Euler identity, J. Inequal. in Pure and Appl. Math., 5, 3 (2004), Article 58.

[3] A. Aglić Aluinović, J. PeČARIĆ, Discrete weighted Montgomery identity and discrete Ostrowski type inequalities, Computers and Mathematics with Applications, 48, (2004), 731-745.

[4] LJ. DEdić, M. MATIĆ, J. PEČARIĆ, AND A. VUKELIĆ, On generalizations of Ostrowski inequality via Euler harmonic identities, J. of Inequal. \& Appl., 7, 6 (2002), 787-805.

[5] LJ. Dedić, M. MATIĆ AND J. PeČARIĆ, On generalizations of Ostrowski inequality via some Euler-type identities, Math. Inequal. \& Appl., 3, 3 (2000), 337-353.

[6] LJ. Dedić, M. Matić And J. PeČARIĆ, On Euler trapezoid formulae, Appl. Math. Comp. 123, (2001) 37-62.

[7] Lj. Dedić, M. Matić AND J. PeČARIĆ, On Euler mid-point formulae, ANZIAM Journal, 46, (2005), 417-438.

[8] S. S. DRAGOMIR, The generalised integration by parts formula for Appell sequences and related results, Commun. Korean Math. Soc., 19, 1 (2004), 75-92. 